\title{
Identification and Bioassay of Allelopathic Substances from Plant and Rhizosphere Soil Extracts of Adzuki Bean (Vigna angularis [Willd.] Ohwi \& H. Ohashi.)
}

\author{
H. Song ${ }^{1,2, \uparrow}$, P. P. Zhang ${ }^{3, \uparrow}$, X. L. Gao ${ }^{1}$, S. X. Xu' ${ }^{2}$, Q. Zhou ${ }^{2}$, B. L. Feng ${ }^{1}$, Y. Fan ${ }^{2}$ \& Y. P. Xie ${ }^{4}$ \\ ${ }^{1}$ State Key Laboratory of Crop Stress Biology in Aried Areas, Northwest A\&F University, Yangling, Shaanxi, \\ China \\ ${ }^{2}$ Anyang Academy of Agriculture Sciences, Anyang, Henan, China \\ ${ }^{3}$ Heilongjiang August First Land Reclamation University, Daqing, Heilongjiang, China \\ ${ }^{4}$ Anyang City Layout and Planning Academy, Anyang, Henan, China \\ Correspondence: H. Song, State Key Laboratory of Crop Stress Biology in Aried Areas, Northwest A\&F \\ University, Yangling, Shaanxi 712100, China. Tel: 86-29-8708-2889. E-mail: songhui@nwsuaf.edu.cn
}

\author{
Received: June 8, $2016 \quad$ Accepted: August 31, $2016 \quad$ Online Published: October 15, 2016 \\ doi:10.5539/jas.v8n11p30 URL: http://dx.doi.org/10.5539/jas.v8n11p30
}

${ }^{\dagger}$ These authors contributed equally to this research.

\begin{abstract}
The soil sickness of Adzuki bean [Vigna angularis (Willd.) Ohwi \& H. Ohashi] have been getting attention seriously under a continuously mono-cropping management-system in China. To investigate the allelopathy of rhizosphere soil and plant of Adzuki bean, culture dish and pot experiments were conducted. The compounds in the products were identified by High Performance Liquid Chromatography (HPLC). The aqueous extracts from rhizospheric soil and whole plant inhibited seed index (seed germination and seed potential) and plant growth under different degrees, and it showed concentration gradient effect on the inhibition of seed germination. Inhibition was stronger with increasment in extract concentration with the highest effect at 0.16 parts aqueous extract to 1 parts deionized water $\left(0.16 \mathrm{~g} \cdot \mathrm{mL}^{-1}\right)$. The impact on growth varied among aqueous extracts from rhizospheric soil and the whole plant. Five phenolic compounds, cinnamic, phthalic, $p$-hydroxybenzoic, and isobutyricand glutaric acids, were detected from the rhizosphere soil and plant extract of Adzuki bean by HPLC method. Cinnamic, phthalic, and $p$-hydroxybenzoicacids were higher than that of the other phenolic acids. This result suggests that autotoxicity effects of phenolics on Adzuki bean probably happen in continuous mono-cropping systems.
\end{abstract}

Keywords: allelopathy, continuous-cropping, seedling growth

\section{Introduction}

Adzuki bean (Vigna angularis (Willd.) Ohwi \& H. Ohashi), as one of the major food legumes in China, has a short growth period, drought-resistance, poor soil fertility, and salinity (Lin, 2002). In traditional medication in China, Adzuki was commonly used for many purposes, such as diuretics and antidotes and symptom alleviations of dropsyand beriberi. Continuous cropping of Adzuki leads to soil sickness, resurgence of disease pest, and exhaustion of soil fertilitywhich affected yield of Adzuki bean. The soil sickness and allelopathic have been partly attribued to autotoxicity (Ram, 2009). Autotoxicity is a process, where a plant or its decomposing residues release toxic chemicals that may inhibit germinationand growth of same plants into the environment (Han et al., 2012; Li et al., 2011), which is common cause of replant problems (Bai et al., 2009; Kalinova et al., 2007). Autotoxicity of root exudates is an important feature for understanding replanting problems in agroecosystem because it represents one of the largest direct inputs of allelochemicals into the rhizosphere environment with potent biological activity and great variation inchemical components (Wu et al., 2007; You et al., 2014). Autotoxicity from root exudates was found to be involved in growth reductionin Glycine max monocropping, which decreased plant biomass and root triphenyl tetrazolium chloride-reducing activity ,seedlings, as well as exhibited higher activities of superoxide dismutase and guaiacol peroxidase (Li et al., 2011). Some phenolic 
acids, including vanilllic acid, p-pydrobenzoic acid, p-oumaric acid, ferulic acid, and its derivatives in root decomposed products or exudates of cuceumbers ( $\mathrm{Wu}, 2009)$, pepper (Geng, 2009), buckwheat (Kalinova, 2007), and cowpea (Huang, 2010) has been reported. Up to date, several reports have referred to physiology and agronomical characters of Adzuki bean (Song et al., 2011; Song et al., 2012a, 2012b). There are no reports about the autotoxins either from the Adzuki bean or from the soil of continuous Adzuki bean cropping. Therefore, identifying and quantifying autotoxins in the whole plant and rhizospheric soil is important.

The objectives of this work were to: a) compare and determine the effects of aqueous extracts made from the whole plant and rhizospheric soil on the growth and antioxidant enzymes in Adzuki bean; b) examine the compounds contained in extracts taken from plants and rhizospheric soil by Adzuki bean; c) test the inhibitory effects of allelochemicals on Adzuki bean seedling performance.

\section{Materials and Methods}

The test was conducted at the No. 1 Agricultural Experiment station of Northwest A\&F University, Yangling, Shaanxi province, China. The station located in the Loess Plateau in southern subhumid areas, $\mathrm{MS}\left(108^{\circ} \mathrm{E}, 34^{\circ} \mathrm{N}\right)$, with an elevation of $520 \mathrm{~m}$ and with an average annual rainfall of $660 \mathrm{~mm}$ (mainly in summer season from July to September).

\subsection{Preparation of extracts}

\subsubsection{Plant Extract}

Fresh whole 5-Adzuki bean plants at full ripening stage were chopped into $0.5-1 \mathrm{~cm}$ long pieces. The parts were oven dried at $60^{\circ} \mathrm{C}$ for 5 days. One hundred and sixty g of dried chopped plant material was extracted by soaking in $1 \mathrm{~L}$ deionized water at $25^{\circ} \mathrm{C}$ for $25 \mathrm{~h}$ in a shaker to give a concentration of $160 \mathrm{~g}$ dry tissue $\mathrm{L}^{-1}\left(0.16 \mathrm{~g} \cdot \mathrm{mL}^{-1}\right)$. The extract was filtered through four layers of cheese cloth to remove fiber debris and centrifuged at $3000 \mathrm{rpm}$ for $4 \mathrm{~h}$ (Chon et al., 2002). The supernatant was filtered through a 0-0.2 mm filter ware unit and filtrate (extract) was kept in a refrigerator at $4{ }^{\circ} \mathrm{C}$ until use.

\subsubsection{Rhizosphere Soil Extract}

At the full ripening stage, 5-Adzuki bean plants were selected randomly and uprooted carefully, and the rhizosphere soil was obtained by gentle shaking from the roots. The soilafter air-dry, was passedthrough a 0.64 $\mathrm{mm}$ sieve. Thereafter, $160 \mathrm{~g}$ of the soilwas suspended in $1 \mathrm{~L}$ of sterile water $\left(0.16 \mathrm{~g} \cdot \mathrm{mL}^{-1}\right)$ and then shakenfor $2 \mathrm{~h}$ at $40{ }^{\circ} \mathrm{C}$ in a vibrating machine. The suspension was allowed to settle for $24 \mathrm{~h}$ at $25^{\circ} \mathrm{C}$, after which the liquid was filtered through a 2-layer gauze and the filtrateobtained was condensedunder vacuum at $25{ }^{\circ} \mathrm{C}$. The dry material was stored in the refrigerator at $4{ }^{\circ} \mathrm{C}$ until use.

\subsection{Seed Bioassay}

Dry plant and rhizosphere soil extracts prepared as above, were diluted with sterile distilled water to $0,0.01,0.04$ and $0.16 \mathrm{~g} \cdot \mathrm{mL}^{-1}$, concentrations. Seed germination tests were conducted for each extract as under: 100 Adzuki bean seeds were surfacesterilized with $5.25 \%(\mathrm{w} / \mathrm{v})$ sodium hypochlorite solution for $15 \mathrm{~min}$, rinsed thrice with distilled water and were evenlyplaced on two-layers of filter paper in sterilized $9 \mathrm{~cm}$ Petri dishes. Ten $\mathrm{ml}$ extract was added per Petri dish and distilled water was used as a control treatment. AllPetri dishes were placed in a darkroom at $25^{\circ} \mathrm{C}$. Treatments were arranged in a completely randomized design with three replications.

The number of seeds germinated was counted daily for 7 days, considering germination when radicle had protruded at least $1 \mathrm{~mm}$ beyond the seed coat. Then, germination potential and germination rate were calculated using the Equations (1) and (2):

Germination rate $(\%)=$ Total number of seeds germinated/Total number of seeds sown $\times 100$

Germination potential $(\%)=$ Total number of seeds germinated at peak/Total number of sown seeds $\times 100$

After 14 days, root length and seedling height of Adzuki bean were measured and dry weights (root, stem, and leaf) was determined by drying the plant material in an oven at $60^{\circ} \mathrm{C}$ for $24 \mathrm{~h}$.

\subsection{HPLC Analysis}

A volume of $4 \mathrm{ml}$ of either soil or plant extracts was extracted thrice with $150 \mathrm{ml}$ of ethyl acetate. The extracts were combined and then concentrated to approximately $2 \mathrm{ml}$ in a rotary evaporator at room temperature and freeze-dried to obtain dried material. The solution was filtered through $0.45 \mu \mathrm{m}$ filters and diluted twicebefore being injected into the HPLC system (Shumadzu model LC20 HPLC system, Shimadzu, Japan) coupled to an UV-VIS detector. System control and data analysis were processed withsoftware following the method described by Porter et al. (1985). Thechromatographic separationwas performed on an ODS-C18, column $(44.6 \times 450 \mathrm{~mm})$ 
using methylalcohol (purity $>98 \%$ ) asmobile phase at a flow rate of $0.5 \mathrm{~mL} \cdot \mathrm{min}^{-1}$. The chromatogram was monitored at a wavelength of $280 \mathrm{~nm}$ throughout the experiment. The column temperature was maintained at $30{ }^{\circ} \mathrm{C}$ and the injection volume of soil and plant extracts and standard solution was $20 \mu \mathrm{l}$. Standards (purity $>$ $98 \%$ ) of cinnamic, phthalic, $p$-hydroxybenzoic, isobutyric and glutaric acids were purchased from Sigma-AldrichCo. (St. Louis, Missouri, USA) were also co-injected.

Identification of the constituents was performed by HPLC-DAD-ESI-MS analysis and/or comparing the retention time, the UV and MS spectra of the peaks from the samples with those ofauthentic reference samples. The purity of the peaks was checked by Diode Array Detector coupled to the HPLC system, comparing the UV spectra of eachpeak with examination of the MS spectra.

\subsection{Autotoxins Assay}

Among the chemicals found in the largest amounts in Adzuki bean plant and rhizospheric soil extracts, phthalic acid, cinnamic acid, and $p$-hydroxybenzoic acid (PHBA), were assayed on seed germination of the Adzuki bean seeds. These chemicals were dissolved in distilledwaterand diluted to get $0.1 \mathrm{mmol} \cdot \mathrm{L}^{-1}, 1 \mathrm{mmol} \cdot \mathrm{L}^{-1}$ and 10 $\mathrm{mmol} \cdot \mathrm{L}^{-1}$ concentrations. Seed Germination tests were conducted with the three chemicals as follows: 100 Adzuki bean seeds were surface sterilized with $10: 1$ water/bleach $(5.25 \% \mathrm{w} / \mathrm{v} \mathrm{NaOCl})$ solution and wereevenly placed on filter paper in sterilized $9 \mathrm{~cm}$ Petri dishes. Ten $\mathrm{ml}$ of a solution of phthalic, cinnamic or $p$-hydroxybenzoic acids were added separately to each Petri dish. An equal amount of distilled water was used as a control. All Petri dishes were placed in illuminated room at $24{ }^{\circ} \mathrm{C}$. Treatments were arranged in a completelyrandomized design with three replications. Germination was monitored by counting the number ofgerminated seeds at $24 \mathrm{~h}$ intervals till 7 days andexpressed as total seeds germination (\%). Radicle lengths were determined after $7 \mathrm{~d}$, and thereafter, seedlings weredried in oven for determining their dry weight.

\subsection{Statistical Analysis}

The data were subjected to one-way analysis of variance, and treatment means separated from the control at $\mathrm{P}<$ 0.05 level of significance, applying posthoc Dunnett's test. All statistical analysis was performed using DPS5.0 for Windows statistical software package.

Responseindex (RI) of allelopathy was calculated using the Equations (3) and (4) asdescribed by Williamson and Richardson (1988):

$$
\begin{array}{ll}
\mathrm{RI}=1-\mathrm{C} / \mathrm{T} & (\mathrm{T} \geq \mathrm{C}) \\
\mathrm{RI}=\mathrm{T} / \mathrm{C}-1 & (\mathrm{~T}<\mathrm{C})
\end{array}
$$

Where, $\mathrm{C}$ is control response, and $\mathrm{T}$ is treatment response. The range of $\mathrm{RI}$ is from -1 to +1 . The positive value indicated stimulation, whereas, the negative value indicated inhibition compared with control.

\section{Results}

\subsection{Effects of Extracts on Germination of Adzuki Bean}

The aqueous extracts from rhizospheric soil and whole plant showed they inhibited seed germination to different degrees and concentration gradient effect on the inhibition ofseed germination (Table 1). Inhibitionwas stronger with increasement in extract concentration, and the inhibitory effect was highest at 0.16 parts aqueous extract to 1 parts deionized water $\left(0.16 \mathrm{~g} \cdot \mathrm{mL}^{-1}\right)$. At the lowest extract concentration of $0.01 \mathrm{~g} \cdot \mathrm{mL}^{-1}$ the seed germination rate in the rhizospheric soil and whole plant extracts was $85 \%$ and $86 \%$, with RI up to 12.3 and 11.3 , the germination potential was $61 \%$ and $65 \%$, with RI -29.8 and -25.2 , at the highest extract concentration of 0.16 $\mathrm{g} \cdot \mathrm{mL}^{-1}$ the germination rate of rhizospheric soil and whole plant extracts was $60 \%$ and $51 \%$. The germination energy was $29 \%$ and $27 \%$. 
Table 1. Effects of rhizospheric soil and plant extracts of Adzuki bean on seeds indexes

\begin{tabular}{|c|c|c|c|c|c|}
\hline \multirow{2}{*}{ Aqueous extracts } & \multirow{2}{*}{ Concentration $\left(\mathrm{g} \cdot \mathrm{mL}^{-1}\right)$} & \multicolumn{2}{|c|}{ Germination rate $(\%)$} & \multicolumn{2}{|c|}{ Germination potential (\%) } \\
\hline & & Mean \pm SD & RI & Mean \pm SD & RI \\
\hline \multirow[t]{4}{*}{ Rhizospheric soil } & 0 & $0.97 \pm 0.23 \mathrm{a}$ & 0.00 & $0.87 \pm 0.11 \mathrm{a}$ & 0.00 \\
\hline & 0.01 & $0.85 \pm 0.16 b$ & -12.3 & $0.61 \pm 0.11 \mathrm{~b}$ & -29.8 \\
\hline & 0.04 & $0.83 \pm 0.22 b$ & -14.4 & $0.49 \pm 0.09 \mathrm{c}$ & -43.6 \\
\hline & 0.16 & $0.60 \pm 0.17 \mathrm{c}$ & -38.1 & $0.29 \pm 0.07 \mathrm{~d}$ & -66.7 \\
\hline \multirow[t]{4}{*}{ Whole plant } & 0 & $0.97 \pm 0.23 \mathrm{a}$ & 0.00 & $0.87 \pm 0.11 \mathrm{a}$ & 0.00 \\
\hline & 0.01 & $0.86 \pm 0.21 b$ & -11.3 & $0.65 \pm 0.09 \mathrm{~b}$ & -25.2 \\
\hline & 0.04 & $0.61 \pm 0.24 \mathrm{c}$ & -37.1 & $0.59 \pm 0.07 \mathrm{c}$ & -32.1 \\
\hline & 0.16 & $0.51 \pm 0.20 \mathrm{~d}$ & -47.4 & $0.27 \pm 0.09 \mathrm{~d}$ & -68.9 \\
\hline
\end{tabular}

Note. RI, response index. Values were the mean \pm SD of each group with three replicates; the different letters in the same column indicated significant differenceamong treatments at 0.05 levels. The same as below.

\subsection{Effects of Extracts on the Growth of Adzuki Bean}

Different extracts had a distinct influence on the growth of roots, stems, and leaves (Table 2). The aqueous extracts showed different degrees of inhibition plant growth, and an extract concentration gradient effect on growth inhibition was observed. Inhibition was stronger with increased in extract concentration, and inhibitory effect was highest with aqueous extracts of $0.16 \mathrm{~g} \cdot \mathrm{mL}^{-1}$. At the lowest extract concentration of $0.1 \mathrm{~g} \cdot \mathrm{ml}^{-1}$, the seedling height in the rhizospheric soil and whole plant extracts was $14.64 \mathrm{~cm}$ and $13.31 \mathrm{~cm}$, respectively; the root length was $164.4 \mathrm{~cm}$ and $149.3 \mathrm{~cm}$; the rootdry weight was $4.11 \mathrm{mg}$ and $3.12 \mathrm{mg}$; the stem dry weight was $357.4 \mathrm{mg}$; the leaf dry weight was $127.4 \mathrm{mg}$ and $117.5 \mathrm{mg}$. The highest extract concentration of $0.16 \mathrm{~g} \cdot \mathrm{ml}^{-1}$, the seedling height in the rhizospheric soil and whole plant extracts was $12.11 \mathrm{~cm}$ and $10.63 \mathrm{~cm}$; the root length was $134.6 \mathrm{~cm}$ and $114.9 \mathrm{~cm}$; the root dry weight was $2.46 \mathrm{mg}$ and $1.11 \mathrm{mg}$; the stem dry weight was $284.1 \mathrm{mg}$ and $258.5 \mathrm{mg}$; the leaf dry weight was $98.0 \mathrm{mg}$ and $81.9 \mathrm{mg}$.

Table 2. Effects of rhizospheric soil and plant extracts of Adzuki bean on seedling growth.

\begin{tabular}{|c|c|c|c|c|c|c|c|c|c|c|c|}
\hline \multirow{2}{*}{$\begin{array}{l}\text { Aqueous } \\
\text { extract }\end{array}$} & \multirow{2}{*}{$\begin{array}{l}\text { Concentration } \\
\left(\mathrm{g} \cdot \mathrm{mL}^{-1}\right)\end{array}$} & \multicolumn{2}{|c|}{ Seedling height $(\mathrm{cm})$} & \multicolumn{2}{|c|}{ Root length (cm) } & \multicolumn{2}{|c|}{ Root dry weight (mg) } & \multicolumn{2}{|c|}{ Stem dry weight (mg) } & \multicolumn{2}{|c|}{ Leafdryweight (mg) } \\
\hline & & Means \pm SD & RI & Means \pm SD & RI & Means \pm SD & RI & Means \pm SD & RI & Means \pm SD & RI \\
\hline \multirow{4}{*}{$\begin{array}{l}\text { Rhizospheric } \\
\text { soil }\end{array}$} & 0 & $14.32 \pm 0.27 \mathrm{a}$ & 0.00 & $162.7 \pm 9.0 \mathrm{a}$ & 0.00 & $3.80 \pm 0.12 \mathrm{a}$ & 0.00 & $3363.7 \pm 11.4 \mathrm{a}$ & 0.00 & $129.4 \pm 9.6 \mathrm{a}$ & 0.00 \\
\hline & 0.01 & $14.64 \pm 0.21 \mathrm{a}$ & 2.05 & $164.4 \pm 10.6 \mathrm{a}$ & 1.03 & $4.11 \pm 0.09 \mathrm{a}$ & 2.97 & $357.4 \pm 12.6 \mathrm{a}$ & -1.76 & $127.4 \pm 13.7 \mathrm{a}$ & -1.57 \\
\hline & 0.04 & $13.44 \pm 0.24 \mathrm{a}$ & -6.72 & $145.6 \pm 14.8 b$ & -11.74 & $3.62 \pm 0.07 \mathrm{a}$ & -2.08 & $321.6 \pm 13.4 \mathrm{~b}$ & -13.09 & $104.2 \pm 10.6 b$ & -24.18 \\
\hline & 0.16 & $12.11 \pm 0.26 \mathrm{a}$ & -18.18 & $134.6 \pm 15.9 \mathrm{~b}$ & -20.88 & $2.46 \pm 0.09 \mathrm{a}$ & -16.67 & $284.1 \pm 12.2 \mathrm{~b}$ & -28.02 & $98.0 \pm 10.4 \mathrm{~b}$ & -32.04 \\
\hline \multirow[t]{4}{*}{ Whole plant } & 0 & $14.32 \pm 0.27 \mathrm{a}$ & 0.00 & $162.7 \pm 9.0 \mathrm{a}$ & 0.00 & $3.80 \pm 0.12 \mathrm{a}$ & 0.00 & $363.7 \pm 11.4 \mathrm{a}$ & 0.00 & $129.4 \pm 9.6 \mathrm{a}$ & 0.00 \\
\hline & 0.01 & $13.41 \pm 0.19 \mathrm{a}$ & -6.72 & $149.3 \pm 25.4 b$ & -8.98 & $3.12 \pm 0.12 \mathrm{a}$ & -8.89 & $334.2 \pm 10.4 \mathrm{~b}$ & -8.83 & $117.5 \pm 10.4 \mathrm{ab}$ & -10.13 \\
\hline & 0.04 & $11.90 \pm 0.24 b$ & -20.17 & $134.1 \pm 18.7 \mathrm{c}$ & -21.33 & $1.83 \pm 0.07 \mathrm{ab}$ & -25.64 & $299.6 \pm 11.9 b$ & -21.40 & $93.2 \pm 11.4 \mathrm{~b}$ & -38.84 \\
\hline & 0.16 & $10.63 \pm 0.27 b$ & -34.91 & $114.9 \pm 23.4 \mathrm{~d}$ & -41.60 & $1.11 \pm 0.07 \mathrm{~b}$ & -38.03 & $258.5 \pm 9.7 \mathrm{c}$ & -40.70 & $81.9 \pm 13.6 \mathrm{c}$ & -58.00 \\
\hline
\end{tabular}

\subsection{Isolation and Identification of Autotoxins}

Comparison of retention time and mass spectra with those of authentic samples, 5 peaks were identified, including cinnamic acid, phthalicacid, p-hydroxybenzoicacid, isobutyricacid, and glutaric acidwith the contents $20.40 \mu \mathrm{g} \cdot \mathrm{g}^{-1}, 29.33 \mu \mathrm{g} \cdot \mathrm{g}^{-1}, 12.88 \mu \mathrm{g} \cdot \mathrm{g}^{-1}, 2.89 \mu \mathrm{g} \cdot \mathrm{g}^{-1}$, and $6.9 \mu \mathrm{g} \cdot \mathrm{g}^{-1}$, respectively (Figure 1). The control soil that had planted bean failed to detect the cinnamic acid and $p$-hydroxybenzoicacid (Table 3 ). In addition, the same components were identified in the rhizosphere soil extract, and their contents were lower than that of plant extracts. 
Table 3. Contents of phenolics compounds forrhizosphere soil, plant and the soil control extracts

\begin{tabular}{lllllll}
\hline Acids & Phthalic acid & Cinnamic acid & p-hydroxybenzoicacid & isobutyricacid & glutaric acid & Total \\
\hline Retention Time $(\min )$ & 7.30 & 4.29 & 5.52 & 3.00 & 3.34 & \\
Contents in rhizospheresoil $(\mu \mathrm{g} / \mathrm{g})$ & $29.33 \pm 1.73$ & $24.40 \pm 1.48$ & $12.88 \pm 1.26$ & $2.89 \pm 0.16$ & $6.9 \pm 0.5 \mathrm{~b}$ & 76.4 \\
Contents in plant $(\mu \mathrm{g} / \mathrm{g})$ & $969.55 \pm 25.36$ & $891.14 \pm 20.17$ & $339.40 \pm 17.2$ & $159.21 \pm 10.34$ & $79.26 \pm 6.87$ & 2438.6 \\
Contents in the soil control $(\mu \mathrm{g} / \mathrm{g})$ & $\mathrm{ND}$ & $3.69 \pm 0.34$ & $\mathrm{ND}$ & $2.88 \pm 0.19$ & $6.97 \pm 0.49$ & 13.54 \\
\hline
\end{tabular}

Note. ND: not detected, nophenolic compounds observed on chromatograms.

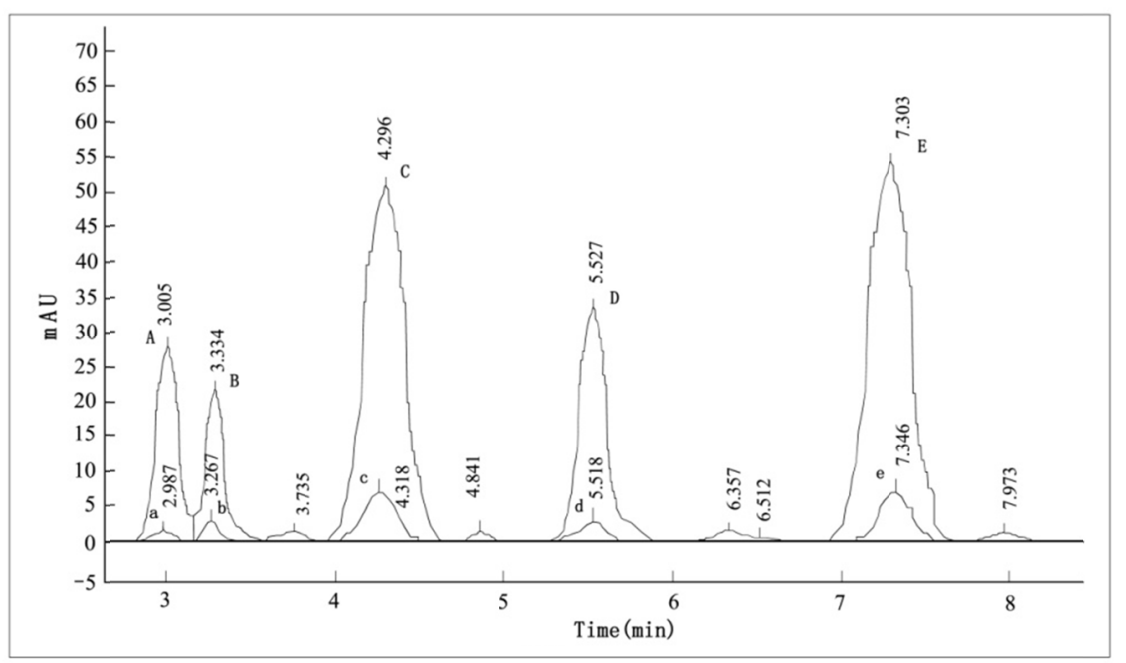

Figure 1. HPLC chromatograms of plant extracts obtained from Adzuki bean. Peaks A, B, C, D and E are standards of isobutyricacid, glutaric acid, cinnamic acid, p-hydroxybenzoicacid, and phthalic acid respectively. Peaks A, B, C, DandEare the corresponding compounds in plant extracts

\subsection{Autotoxicity Tests with Allelochemicals}

Three allelochemicals had some phytotoxicity on Adzuki bean seedling growth (Table 4). Growth parameters varied considerably with the allelochemicals and extractconcentration. Germination, radicle length, and total dry weightof Adzuki bean seedlings were greatly reduced by phthalic acid, the decrement was 44, 59.1, and 61\%, respectively.At the concentration of $10 \mathrm{mmol} \cdot \mathrm{L}^{-1}$. The same change trend was also observed for cinnamic acid. The $p$-hydroxybenzoic acid had positive effects on germination, radical length, and total dry weight at the lowest concentration assayed $\left(0.01 \mathrm{mmol} \cdot \mathrm{L}^{-1}\right)$; the increment was $13.4 \%, 16.1 \%$ and $32.3 \%$, respectively. However, the high concentration $\left(10 \mathrm{mmol} \cdot \mathrm{L}^{-1}\right)$ of $p$-hydroxybenzoic acidlowered the root length and total dry weight. In general, allelochemicals phytotoxicity on seedling growth was much stronger as concentration increased. In addition, among the three chemicals, phthalic acid was the most toxic. 
Table 4. Effects of three phenolic acid on germination and growth of Adzuki bean

\begin{tabular}{lllll}
\hline Phenolic Acids & Concentration $\left(\mathrm{mmol} \cdot \mathrm{L}^{-1}\right)$ & ${\text { Germination }(\%)^{1}}^{1}$ & ${\text { Radicle length }(\mathrm{mm})^{1}}^{\text {Dry weight }_{(\mathrm{g})^{1}}}$ \\
\hline Control & 0 & $98.4 \pm 2.8 \mathrm{a}$ & $9.3 \pm 0.9 \mathrm{a}$ & $1.67 \pm 0.31 \mathrm{a}$ \\
Phthalic acid & 0.1 & $73.2 \pm 3.3 \mathrm{ab}$ & $6.9 \pm 0.5 \mathrm{~b}$ & $1.33 \pm 0.12 \mathrm{a}$ \\
& 1 & $68.5 \pm 3.5 \mathrm{~b}$ & $5.3 \pm 0.3 \mathrm{c}$ & $0.95 \pm 0.14 \mathrm{~b}$ \\
& 10 & $55.1 \pm 5.1 \mathrm{c}$ & $3.8 \pm 0.5 \mathrm{c}$ & $0.65 \pm 0.09 \mathrm{~b}$ \\
Cinnamic acid & 0.1 & $79.8 \pm 3.6 \mathrm{~b}$ & $7.8 \pm 0.4 \mathrm{a}$ & $1.46 \pm 0.15 \mathrm{a}$ \\
& 1 & $73.6 \pm 4.1 \mathrm{bc}$ & $6.1 \pm 0.5 \mathrm{~d}$ & $1.22 \pm 0.20 \mathrm{ab}$ \\
p-Hydroxybenzoic acid & 0.01 & $64.7 \pm 2.5 \mathrm{c}$ & $4.7 \pm 0.7 \mathrm{c}$ & $0.87 \pm 0.17 \mathrm{~b}$ \\
& 0.1 & $83.6 \pm 5.1 \mathrm{a}$ & $7.6 \pm 0.2 \mathrm{a}$ & $1.43 \pm 0.12 \mathrm{ab}$ \\
& 1 & $78.2 \pm 4.2 \mathrm{~b}$ & $6.9 \pm 0.3 \mathrm{ab}$ & $1.14 \pm 0.13 \mathrm{~b}$ \\
& 10 & $70.8 \pm 3.9 \mathrm{~b}$ & $5.4 \pm 0.2 \mathrm{~b}$ & $0.80 \pm 0.10 \mathrm{~b}$ \\
\hline
\end{tabular}

Note. Different letters indicate significant difference at $5 \%$ probability level.

\section{Discussion}

Extracts of Adzuki bean plant and rhizosphere soil showed inhibitory activity against both germination rate and germination potential. These results suggest that the extracts of plant and rhizosphere soil may contain allelopathic substances that can inhibit the growth of Adzuki bean. The degree of inhibition increased with increasing in extract concentration. At the highest extract concentration $\left(0.16 \mathrm{~g} \cdot \mathrm{mL}^{-1}\right)$, plant extracts significantly reduced seed germination rate and germination energy compared with distilled water control. This finding is supported by Chung and Miller (Chung \& Miller, 1995). Plant extracts were more inhibitory than rhizosphere soil at all concentrations. The result in this study is congruency with that of Turk and Tawaha (2002). During the soil sample collection process, a large amount of fibrous root and leaves residue was left in the soil after harvest (Chon et al., 2002; Chung \& Miller, 1995; Hisashi et al., 2010). It is likely that the autotoxic compounds found in soils are derived partly from root exudates or fromplant tissue degradation. Once released into the soil and accumulated, these compounds may play an important role in mediating the alleged autotoxic effects that interfere with seedling growth of Adzuki bean.

The extract was purified and main inhibitory substances were determined by spectral data as cinnamic acid phthalicacid, p-hydroxybenzoicacid, isobutyricacid, and glutaric acid. The autotoxicity of phthalic acid, cinnamic acid, and its derivatives in root decomposed products or exudates of cuceumbers, and peas has been reported,phthalicacid, p-hydroxybenzoicacid, isobutyricacid, and glutaric acid were identified from the phytotoxic acidic fractionof the root exudates of soybean (Kong \& Xu, 2003; Williamoson \& Richardson, 1988; Xiao et al., 2014). Coumaric acid, long chain fatty acids and phenolic substances with the low content, were also identified in decomposed maize straw products, and the allelopathy of some compounds also has been reported (Lin et al., 2002; Asaduzzaman \& Asao, 2012; Röhrig et al., 2013; Wang et al., 2014). Nevertheless, this is the first report of the presence of cinnamic acid phthalicacid, p-hydroxybenzoicacid, isobutyricacid, and glutaric acid in Adzuki bean extracts from plant extract and rhizospheresoil of Adzuki bean. This result in this study together with previous findings suggest that the majority of compounds identified in decomposed products are likely as the important autotoxicity. However, compounds with the greater autotoxicity to the soil-born pathogens need to be further characterized.

Plants are able to secrete a wide range of compounds into the rhizosphere. Through the secretion of the compounds, plants are able to change chemical and physical propertiesto regulate the soil microbial community and inhibit the growth of other plants. In this study, the control soil (the soil without plant bean) is failed to detect the cinnamic acid and $p$-hydroxybenzoicacid, indicating that five compounds that may be from leaching, root exudation,volatilization and decomposition of plant residues were released into the rhizosphere, they changed soil microbial community and inhibited the growth of Adzuki bean.

\section{References}

Asaduzzaman, M., \& Asao, T. (2012). Autotoxicity in beans and their allelochemicals. Sci Hortic-Amsterdam., 134, 26-31. http://dx.doi.org/10.1016/j.scienta.2011.11.035

Bai, R., Zhao, X., Ma, F. W., \& Li, C. Y. (2009). Identification and bioassay of allelopathic substances from the root exudates of Malus prunifolia. Allelopathy J., 23, 477-484. 
Chon, S. U., Choi, S. K., Jung, S., Jang, H. G., Pyo, B. S., \& Kim, S. M. (2002). Effects of alfalfa leaf extracts and phenolic allelochemicals on early seedling growth and root morphology of alfalfa and barnyard grass. Crop Prot., 21, 1077-1082. http://dx.doi.org/10.1016/S0261-2194(02)00092-3

Chung, I. M., \& Miller, D. A. (1995). Natural herbicide potential of alfalfa residues on selected weed species. Agro J., 87, 920-925. http://dx.doi.org/10.2134/agronj1995.00021962008700050024x

Geng, G. D., Zhang, S. Q., \& Cheng, Z. H. (2009).Allelopathy and allelochemicals of root exudates in hot pepper. Acta Hortic Sin, 36, 873-878. http://dx.doi.org/10.16420/j.issn.0513 -353x.2009.06.018

Han, C. M., Li, C. L., Ye, S. P., Wang, H., Pan, K. W., Wu, N., ... Zhang, L. (2012). Autotoxic effects of aqueous extracts of ginger on growth of ginger seedings and on antioxidant enzymes, membrane permeability and lipid peroxidation in leaves. Allelopathy J., 30, 259-270.

Hisashi, K. N., Takahiro, S., \& Hideyuki, S. (2010). Allelopathy and allelopathic substance in the moss rhynchoste gium pallidifolium. J Plant Physiol., 167, 468-471. http://dx.doi.org/10.1016/j.jplph.2009. 10.018

Huang, X. X. (2010). Identification of autotoxins in rhizosphere soils under the continuous cropping of cowpea. Allelopathy J., 25, 383-392.

Kalinova, J., Vrchotova, N., \& Triska, J. (2007). Exudation of allelopathic substances in buckwheat. J Agr Food Chem., 55, 6453-6459. http://dx.doi.org/10.1021/jf070795u

Kong, C. H., \& Xu, X. H. (2003). Isolation and structure elucidation of organic (pp. 67-68). Beijing: Chemical Industry Press.

Li, Y., Huang, X. F., \& Ding, W. L. (2011). Autotoxicity of Panax ginseng rhizosphere and non-rhizosphere soil extracts on early seedlings growth and identification of chemicals. Allelopathy J., 28, 145-154.

Lin, R. F., Chai, Y., \& Liao, Q. (2002). Minor Grain Crops in China (pp. 192-209). Beijing, Agricultural Science and Technology Press.

Munir, A. T., \& Tawaha, A. R. M. (2002). Inhibitory effects of aqueous extracts of black mustard on germination and growth of lentil. Pak J Agron., 1, 28-30. http://dx.doi.org/10.3923/ja.2002.28.30

Porter, P. M., Banwart, W. L., \& Hassett, J. J. (1985). HPLC isolation and GC-MS identification of genistein, daidzein and coumestrol from unhydrolyzed soybean root extracts. Environ Exp Bot., 25, 29-232. http://dx.doi.org/10.1016/0098-8472(85)90006-1

Ram, C. S. (2009). Cereal-Based Cropping Systems in Asia. Nutrition and Disease Management (pp. 99-119). Crop Physiology Applications for Genetic Improvement and Agronomy Acdimic Press.

Röhrig, J., Kastner, C., \& Fischer, R. (2013). Light inhibits sporegermination through phytochrome in Aspergillus nidulans. Curr Genet., 59, 55-62. http://dx.doi.org/10.1007/s00294-013-0387-9

Song, H., Feng, B. L., Gao, X. L., Dai, H. P., \& Zhang, P. P. (2011). Relationship between root activity and leaf senescence in different Adzuki bean cultivars (lines). Acta Bot Bor-Occid Sin., 11, 2270-2275.

Song, H., Gao, J. F., Gao, X. L., Dai, H. P., Zhang, P. P., Wang, P. K., ... Feng, B. L. (2012a). Relations between photosynthetic parameters and seed yields of Adzuki bean cultivars (Vigna angularis). J Integr Agr., 11, 1453-1461. http://dx.doi.org/10.1016/S2095-3119(12)60145-2

Song, H., Gao, X. L., Zhang, P. P., Dai, H. P., Chen, J., Jiang, S. H., .. Feng, B. L. (2012b). Leaf senescence and physiological characters in different Adzuki bean (Vigna angularis) cultivars (lines). J Food Agric Environ., 10, 132-137. http://dx.doi.org/10.5897/AJAR11.1827

Wang, M. S., Kang, J. C., \& Wang, H. C. (2014). Study of autointoxication of tobacco root in the crude extract. Soil Fert Sci., 4, 91-96.

Williamson, G. B., \& Richardson, D. (1988). Bioassays for allelopathy: Measuring treatment responses with independent controls. $J$ Chem Ecol., 14, 181-187. http://dx.doi.org/10.1007/BF01022540

Wu, F. Z., Wang, X. Z., \& Xue, C. Y. (2009). Effect of cinnamic acid on soil microbial characteristics in the cucumber rhizosphere. Eur J Soil Biol., 45, 356-362. http://dx.doi.org/10.1016/j.ejsobi.2009.04.001

Wu, F. Z., Wang, X. Z., Wang, S. M., \& Zhao, X. G. (2007). Effects of cinnamic acid application on the contents in cucumber plants and soil. Allelopathy J., 20,363-370. 
Xiao, G. L., Chang, F. D., \& Ke, H. (2014). Soil sickness of peanuts is attributable to modifications in soil microbes induced by peanut root exudates rather than to direct allelopathy. Soil Biol Biochem., 78, 149-159. http://dx.doi.org/10.1016/j.soilbio.2014.07.019

You, M. Y., Yuan, Y. R., Li, L. J., Xu, Y. L., \& Han, X. Z. (2014). Soil $\mathrm{CO}_{2}$ emissions as affected by $20-$ Year continuous cropping in Mollisols. J Integr Agr., 13, 615-623. http://dx.doi.org/10.1016/S2095-3119(13) 60719-4

\section{Copyrights}

Copyright for this article is retained by the author(s), with first publication rights granted to the journal.

This is an open-access article distributed under the terms and conditions of the Creative Commons Attribution license (http://creativecommons.org/licenses/by/4.0/). 